Decompositi on Char act er i st i cs of Benzene, Tol uene and Xyl ene in an At nospheri c Pressure DC Cor ona Di scharge II. Char acteristics of Deposi ted By-products and Decomposi ti on Process

\begin{tabular}{|l|l|}
\hline 著者 & $\begin{array}{l}\text { SAKAl Se } \mathrm{j} \mathrm{i}, \text { TAKAHASH Kazuhi ro, SATOH Kohki , } \\
\text { I TOH H denor i }\end{array}$ \\
\hline 杂隹誌名 & Journal of Advanced Oxi dat i on Technol ogi es \\
\hline 巻 & 19 \\
\hline 号 & 1 \\
\hline ○ージ & $59-65$ \\
\hline 発行年 & $2016-01$ \\
\hline URL & $\mathrm{ht} \mathrm{t} \mathrm{p:} \mathrm{//hdl} \mathrm{.} \mathrm{handl} \mathrm{e.} \mathrm{net} / 10258 / 00009594$ \\
\hline
\end{tabular}




\title{
Decomposition Characteristics of Benzene, Toluene and Xylene in an Atmospheric Pressure DC Corona Discharge II. Characteristics of Deposited By-products and Decomposition Process
}

\author{
Seiji Sakai ${ }^{1}$, Kazuhiro Takahashi ${ }^{2}$, Kohki Satoh*, 1, 2, Hidenori Itoh ${ }^{1}$ \\ ${ }^{1}$ Division of Information and Electronic Engineering, Graduate School of Engineering, Muroran Institute of \\ Technology, 27-1, Mizumoto, Muroran 050-8585, Japan \\ ${ }^{2}$ Center of Environmental Science and Disaster Mitigation for Advanced Research, Muroran Institute of \\ Technology, 27-1, Mizumoto, Muroran 050-8585, Japan
}

\begin{abstract}
:
Gaseous by-products and deposited material obtained from the decomposition of benzene, toluene and xylene in an atmospheric pressure DC corona discharge were minutely investigated by gas chromatograph mass spectrometry and infrared absorption spectroscopy, and the decomposition processes of benzene, toluene and xylene were estimated. It was found that carbon dioxide $\left(\mathrm{CO}_{2}\right)$, carbon monoxide $(\mathrm{CO})$, formic acid $(\mathrm{HCOOH})$ and formic anhydride $\left((\mathrm{CHO})_{2}\right)$ were the major gaseous by-products from benzene, toluene and xylene, while acetic formic anhydride $\left(\mathrm{CH}_{3} \mathrm{COOCHO}\right)$ and acetic acid $\left(\mathrm{CH}_{3} \mathrm{COOH}\right)$ were the major by-products from toluene and xylene. Benzaldehyde $\left(\mathrm{C}_{6} \mathrm{H}_{5} \mathrm{CHO}\right)$ and methyl benzaldehyde $\left(\mathrm{CH}_{3} \mathrm{CH}_{4} \mathrm{CHO}\right)$ were produced from toluene and xylene, respectively. It was hypothesized that the decomposition of benzene, toluene, and xylene was initiated by the production of phenyl radicals, phenyl and benzyl radicals, and methyl benzyl and methyl phenyl radicals, respectively. These radicals are deposited on electrodes, wall, etc., resulting in the polymerization of aromatic rings and the substitution of function groups. Also, those radicals are decomposed and converted into by-products described above. In addition, it is probably that benzyl and methyl benzyl radicals are precursors of $\mathrm{C}_{6} \mathrm{H}_{5} \mathrm{CHO}$ and $\mathrm{CH}_{3} \mathrm{C}_{6} \mathrm{H}_{4} \mathrm{CHO}$, respectively, and that $\mathrm{C}_{6} \mathrm{H}_{5} \mathrm{CHO}$ and $\mathrm{CH}_{3} \mathrm{C}_{6} \mathrm{H}_{4} \mathrm{CHO}$ are decomposed, contributing to by-product production and deposition. Furthermore, some intermediate by-products, produced by the cleavage of the aromatic ring in benzene, toluene and xylene decomposition and containing $\mathrm{O}=\mathrm{C}-\mathrm{O}, \mathrm{C}=\mathrm{O}$, $\mathrm{O}-\mathrm{H}$, and $\mathrm{C}-\mathrm{H}$ groups, may be deposit on the electrodes.
\end{abstract}

\section{Introduction}

In general, volatile organic compounds (VOCs), such as benzene, toluene and xylene, are known to produce suspended particulate matter and photochemical oxidants, hence, effective treatment methods for eliminating VOCs in exhaust gases are required. So far, conventional methods, including thermal or catalytic oxidation, adsorption, etc., have been used to remove VOCs in the gas phase, although these have some limitations (1). Recently, plasma treatment of VOCs has attracted attentions, and decomposition rate and efficiency for decomposing the VOCs by active species, such as $\mathrm{O}_{3}, \mathrm{O}$ and energetic species like electrons, ions and excited molecules, in corona discharge (2-4), dielectric barrier discharge (5-7), surface discharge (8), etc. have been discussed. Although decomposition rate and efficiency are the most important factors for the practical use of gas clean-up techniques, it is also necessary to clarify the

*Corresponding author; E-mail: ksatoh@mmm.muroran-it.ac.jp decomposition processes of the VOCs, through detailed analyses of by-products, to ensure effective control of the plasma treatment of the VOCs. Further, this may enable by-product control in VOCs plasma treatment.

Previously, Huang et al. (9) investigated gaseous by-products from the catalytic decomposition of toluene in a dielectric barrier discharge reactor. Benzaldehyde, phenol, nitro benzene, etc. were identified as by-products, and the decomposition processes of toluene with and without the catalyst were estimated. Satoh et al. (10) thoroughly investigated gaseous by-products from benzene, toluene and xylene in an atmospheric pressure DC corona discharge. Seven, thirteen and thirteen by-products were respectively identified in benzene, toluene and xylene decomposition, and their decomposition processes were subsequently elucidated. Also, 30 46 $\%$ of carbon atoms in benzene, toluene and xylene were deposited on electrodes and the wall of the discharge chamber, but the deposited material was not identified. As far as we know, examinations for the 


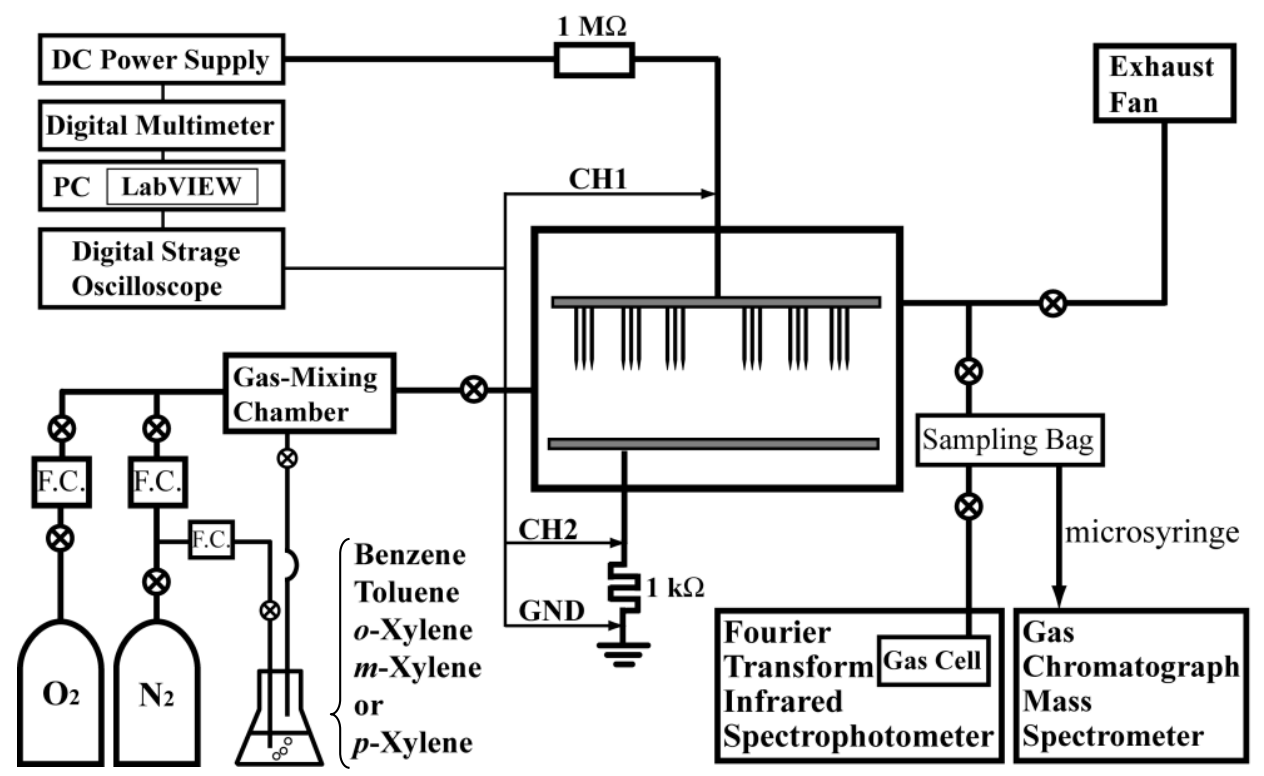

Figure 1. Schematic diagram of experimental apparatus.

decomposition processes of the VOCs based on the detailed analyses of gaseous and deposited byproducts has been reported in few papers.

In this work, we minutely investigated gaseous by-products and deposited material obtained from the deposition of benzene $\left(\mathrm{C}_{6} \mathrm{H}_{6}\right)$, toluene $\left(\mathrm{C}_{6} \mathrm{H}_{5} \mathrm{CH}_{3}\right)$ and xylene $\left(o-, m\right.$ - and $\left.p-\mathrm{C}_{6} \mathrm{H}_{4}\left(\mathrm{CH}_{3}\right)_{2}\right)$ in an atmospheric pressure DC corona discharge, and their decomposition processes from benzene, toluene and xylene to end products, via intermediate by-products, were elucidated.

\section{Experimental Apparatus}

Figure 1 shows a schematic diagram of the experimental apparatus. A multi-needle electrode and a planar electrode were placed in an acrylic cylindrical chamber with $190 \mathrm{~mm}$ inner diameter and $61 \mathrm{~mm}$ height. The multi-needle electrode consisted of 18 clusters, each of which had $6(3 \times 2)$ stainless-steel needles, with $1.5 \mathrm{~mm}$ diameter and $16 \mathrm{~mm}$ length, placed at the intervals of $4 \mathrm{~mm}$. The distance between the planar electrode, a stainless-steel plate $(150 \times 55$ $\mathrm{mm})$, and the tip of the multi-needle electrode was fixed at $15 \mathrm{~mm}$. A test gas, composing a mixture of artificial air $\left(\mathrm{N}_{2} / \mathrm{O}_{2}=80 / 20 \%\right)$ and a VOC (benzene, toluene, $o$-xylene, $m$-xylene, or $p$-xylene) bubbled with $\mathrm{N}_{2}$, was fed into the discharge chamber at a constant gas flow rate of $3.0 \mathrm{~L} / \mathrm{min}$. The pressure in the discharge chamber was atmospheric pressure, and the initial concentration of the VOC was fixed at 800 $\mathrm{ppm}$. A positive DC high voltage of $14.0-14.8 \mathrm{kV}$ was applied to the multi-needle electrode to generate a streamer corona discharge between the electrodes, with input power and discharge time of $15 \mathrm{~W}$ and 30 min, respectively. Gaseous by-products from benzene, toluene and xylene were identified using a gas chromatograph mass spectrometer (GCMS; Shimadzu Corp, GCMS-QP2010 Plus) and a Fourier-transform Infrared (FTIR) Spectrophotometer (Shimadzu Corp, FTIR-8900) equipped with a gas cell (Infrared Analysis Inc., 10-PA) with an optical path length of $10 \mathrm{~m}$. Also, the transmittance of the material deposited material on a Si wafer $(10 \mathrm{~mm} \times 10 \mathrm{~mm} \times 0.5 \mathrm{~mm}$, resistivity > 5 $\Omega \cdot \mathrm{cm}$ ) on the planar electrode was measured by FTIR.

\section{Results and Discussion \\ Gaseous By-products}

Figure 2 shows the chromatograms of gas sampled from the decomposition of benzene, toluene, $o$-xylene, $m$-xylene and $p$-xylene. Benzaldehyde $\left(\mathrm{C}_{6} \mathrm{H}_{5} \mathrm{CHO}\right)$ and $o$-methylbenzaldehyde $\left(o-\mathrm{CH}_{3} \mathrm{C}_{6} \mathrm{H}_{4} \mathrm{CHO}\right)$ were detected at the retention time of $19.75 \mathrm{~min}$ and (2) $0.45 \mathrm{~min}$ in $o$-xylene and $m$-xylene decomposition, respectively. Also, $p$-methylbenzaldehyde ( $p$ $\mathrm{CH}_{3} \mathrm{C}_{6} \mathrm{H}_{4} \mathrm{CHO}$ ) was detected at (3) $0.68 \mathrm{~min}$ in $p$ xylene decomposition. $\mathrm{C}_{6} \mathrm{H}_{5} \mathrm{CHO}$ and $\mathrm{CH}_{3} \mathrm{C}_{6} \mathrm{H}_{4} \mathrm{CHO}$ were probably produced by the substitution of a methyl group $\left(\mathrm{CH}_{3}\right)$ with an aldehyde group $(\mathrm{CHO})$ in toluene and xylene molecules, respectively, since benzaldehyde and methyl benzaldehyde are only detected in toluene and xylene decomposition.

Figure 3 shows the absorbance spectra of gases sampled from the decomposition of benzene with and without discharge obtained by infrared absorption spectroscopy (IRAS). The intensity of absorption peaks corresponding to benzene (673 and $3068 \mathrm{~cm}^{-1}$ ) decreased on using the corona discharge, while peaks 


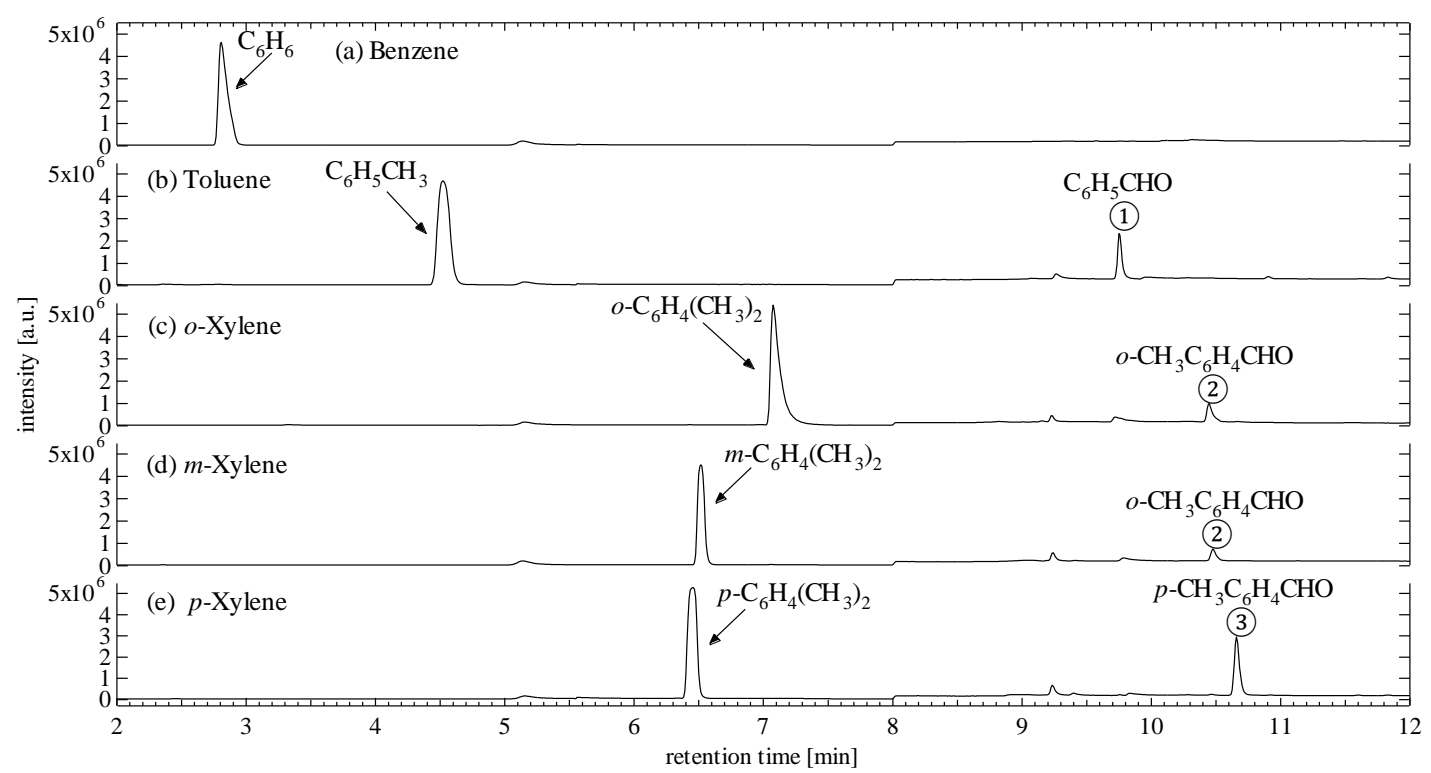

Figure 2. Chromatograms of sampled gases in benzene, toluene and xylene decomposition.

corresponding to carbon dioxide $\left(\mathrm{CO}_{2} ; 2349 \mathrm{~cm}^{-1}\right)$, carbon monoxide $\left(\mathrm{CO} ; 2143 \mathrm{~cm}^{-1}\right)$, formic acid $\left(\mathrm{HCOOH} ; 1105\right.$ and $\left.1770 \mathrm{~cm}^{-1}\right)$, formic anhydride $\left((\mathrm{CHO})_{2} \mathrm{O}\right.$, abbreviated as $\mathrm{FAH} ; 1105,1767$ and 1822 $\left.\mathrm{cm}^{-1}\right)$, acetylene $\left(\mathrm{C}_{2} \mathrm{H}_{2} ; 730 \mathrm{~cm}^{-1}\right)$, hydrogen cyanide $\left(\mathrm{HCN} ; 712 \mathrm{~cm}^{-1}\right)$, maleic anhydride $\left(\mathrm{C}_{4} \mathrm{H}_{2} \mathrm{O}_{3}\right.$, abbreviated as MAH; $\left.1805 \mathrm{~cm}^{-1}\right)$, ozone $\left(\mathrm{O}_{3} ; 1042 \mathrm{~cm}^{-1}\right)$ and nitrous oxide $\left(\mathrm{N}_{2} \mathrm{O} ; 2224 \mathrm{~cm}^{-1}\right)$ were newly observed. Also, minute absorption peaks corresponding to glyoxal $\left((\mathrm{CHO})_{2}\right.$, abbreviated as GLY; $\left.2835 \mathrm{~cm}^{-1}\right)$ and formaldehyde (HCHO; 2783 and $\left.2843 \mathrm{~cm}^{-1}\right)$ were found between 2750 and $2860 \mathrm{~cm}^{-1}$ in a magnified spectrum.

Figure 4 shows the absorbance spectra of gases sampled from toluene decomposition with and without discharge. The intensity of absorption peaks corresponding to toluene $\left(729\right.$ and $\left.3029 \mathrm{~cm}^{-1}\right)$ decreased on using the corona discharge, while peaks corresponding to benzaldehyde $\left(\mathrm{C}_{6} \mathrm{H}_{5} \mathrm{CHO} ; 1730 \mathrm{~cm}^{-1}\right)$, which was also detected by GCMS, acetic formic anhydride $\left(\mathrm{CH}_{3} \mathrm{COOCHO}\right.$, abbreviated as $\mathrm{AFAH}$; $\left.1178 \mathrm{~cm}^{-1}\right)$, peroxyacetyl nitrate $\left(\mathrm{CH}_{3} \mathrm{COOONO}_{2}\right.$, abbreviated as PAN; 794 and $1163 \mathrm{~cm}^{-1}$ ), acetic acid $\left(\mathrm{CH}_{3} \mathrm{COOH} ; 1182 \mathrm{~cm}^{-1}\right)$ and methane $\left(\mathrm{CH}_{4} ; 3019\right.$ $\mathrm{cm}^{-1}$ ) were detected in addition to the benzene decomposition by-products peaks. Absorption peaks corresponding to GLY and $\mathrm{HCHO}$ were found between 2750 and $2860 \mathrm{~cm}^{-1}$ in a magnified spectrum, as shown in benzene decomposition. A minute absorption peak corresponding to methyl glyoxal $\left(\mathrm{CH}_{3} \mathrm{COCHO}\right.$, abbreviated as MGLY; $\left.2829 \mathrm{~cm}^{-1}\right)$ was identified by separating the peaks of GLY and HCHO from the spectra obtained for decomposition with discharge.
Figure 5 shows the absorbance spectra of gases sampled from $o$-xylene decomposition. Apart from $\mathrm{C}_{6} \mathrm{H}_{5} \mathrm{CHO}$, the absorption peaks were the same as those obtained in toluene decomposition, the same by-products were also observed in $m$-xylene decomposition. Figure 6 shows the absorbance spectra of gases sampled from $p$-xylene decomposition. The absorption peak corresponding to p-methylbenzaldehyde $\left(p-\mathrm{CH}_{3} \mathrm{C}_{6} \mathrm{H}_{4} \mathrm{CHO} ; 1725 \mathrm{~cm}^{-1}\right)$ was newly detected in addition to the absorption peaks observed for $o$-xylene and $m$-xylene decomposition by-products.

From these results, it was concluded that $\mathrm{CO}_{2}$, $\mathrm{CO}, \mathrm{HCOOH}, \mathrm{FAH}, \mathrm{C}_{2} \mathrm{H}_{2}, \mathrm{HCN}, \mathrm{HCHO}, \mathrm{MAH}$ and GLY are common gaseous by-products obtained from the decomposition of benzene, toluene and xylene in corona discharge, while $\mathrm{AFAH}, \mathrm{CH}_{3} \mathrm{COOH}$, PAN, $\mathrm{CH}_{4}$ and MGLY are produced only in artificial air containing toluene and xylene. These by-products are produced after the cleavage of an aromatic ring of benzene, toluene and xylene. $\mathrm{C}_{6} \mathrm{H}_{5} \mathrm{CHO}$ and $p$ $\mathrm{CH}_{3} \mathrm{C}_{6} \mathrm{H}_{4} \mathrm{CHO}$ are probably produced from toluene and $p$-xylene, respectively, by the substitution of a methyl group with an aldehyde group.

Table 1 shows the concentrations of the gaseous by-products detected by IRAS, and the decomposition rates of benzene, toluene, and xylene are shown in brackets. The values shown in the table were obtained by averaging at least three measurements, and the deviation of the values is less than $5 \%$. The major gaseous by-products from benzene, toluene, and xylene decomposition are $\mathrm{CO}_{2}, \mathrm{CO}, \mathrm{HCOOH}$ and $\mathrm{FAH}$, and those concentrations exceed $10 \mathrm{ppm}$. AFAH and $\mathrm{CH}_{3} \mathrm{COOH}$ are the major gaseous by-products 


\section{S. Sakai et al.}

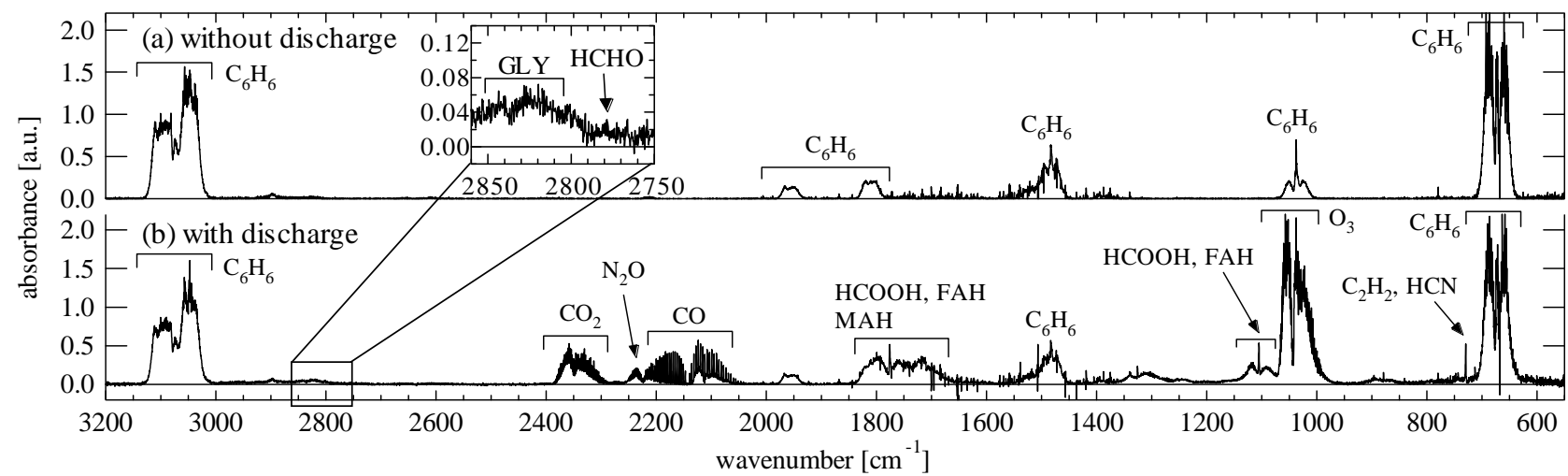

Figure 3. Absorbance spectra of sampled gases in benzene decomposition with and without discharge.

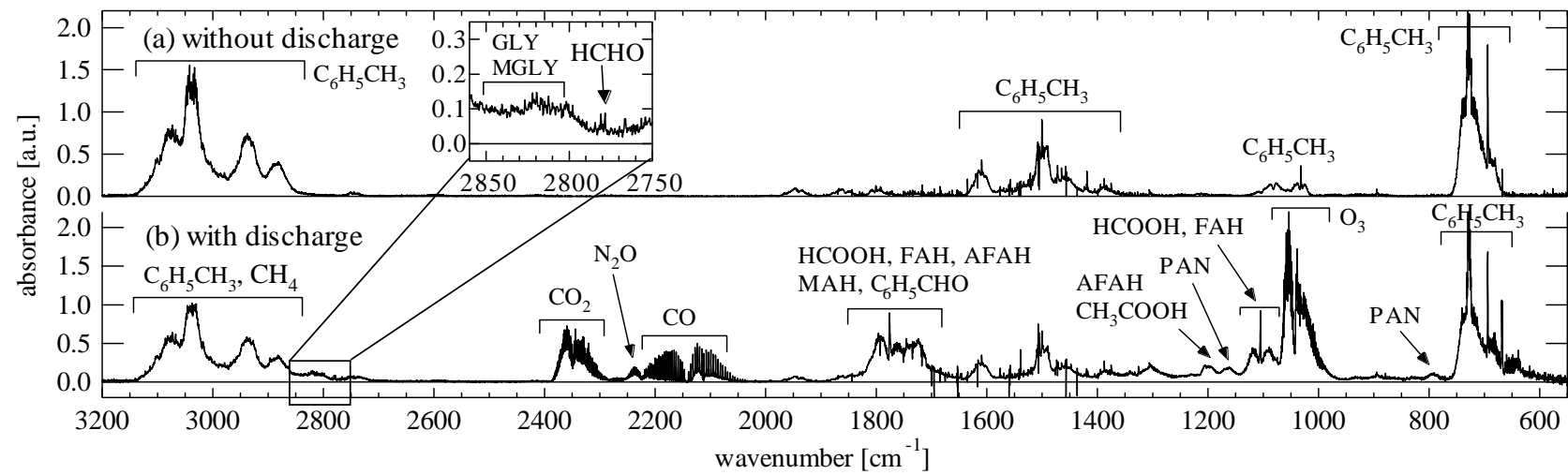

Figure 4. Absorbance spectra of sampled gases in toluene decomposition with and without discharge.

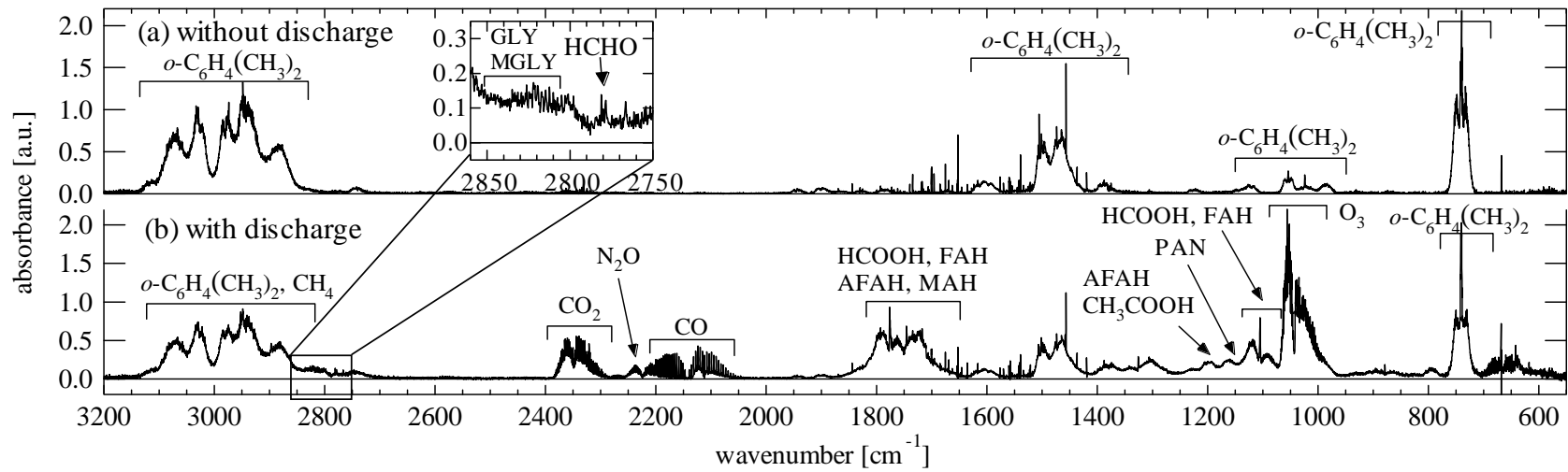

Figure 5. Absorbance spectra of sampled gases in $o$-xylene decomposition with and without discharge.

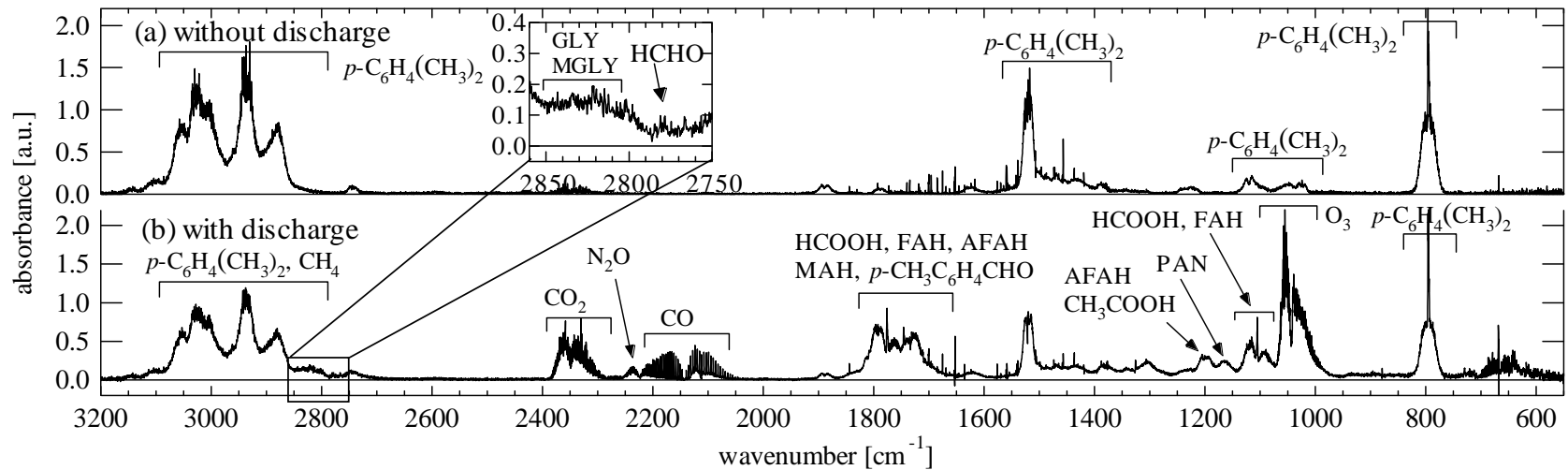

Figure 6. Absorbance spectra of sampled gases in $p$-xylene decomposition with and without discharge. 
Table 1. Concentrations of benzene, toluene, xylene and gaseous by-products.

\begin{tabular}{|c|c|c|c|c|c|}
\hline \multirow{2}{*}{ Substances } & \multicolumn{5}{|c|}{ Concentration (ppm) } \\
\hline & $\mathrm{C}_{6} \mathrm{H}_{6}$ & $\mathrm{C}_{6} \mathrm{H}_{5} \mathrm{CH}_{3}$ & $o-\mathrm{C}_{6} \mathrm{H}_{4}\left(\mathrm{CH}_{3}\right)_{2}$ & $m-\mathrm{C}_{6} \mathrm{H}_{4}\left(\mathrm{CH}_{3}\right)_{2}$ & $p-\mathrm{C}_{6} \mathrm{H}_{4}\left(\mathrm{CH}_{3}\right)_{2}$ \\
\hline $\mathrm{C}_{6} \mathrm{H}_{6}$ & $\begin{array}{c}670 \\
(15.7 \%)\end{array}$ & - & - & - & - \\
\hline $\mathrm{C}_{6} \mathrm{H}_{5} \mathrm{CH}_{3}$ & - & $\begin{array}{c}562.3 \\
(29.4 \%)\end{array}$ & - & - & - \\
\hline $\mathrm{C}_{6} \mathrm{H}_{4}\left(\mathrm{CH}_{3}\right)_{2}$ & - & - & $\begin{array}{c}566.3 \\
(29.3 \%)\end{array}$ & $\begin{array}{c}520.6 \\
(34.8 \%)\end{array}$ & $\begin{array}{c}617.0 \\
(24.1 \%)\end{array}$ \\
\hline $\mathrm{CO}_{2}$ & 104.3 & 170.7 & 132.8 & 161.2 & 161.2 \\
\hline $\mathrm{CO}$ & 170.5 & 152.6 & 104.8 & 135.7 & 119.8 \\
\hline $\mathrm{HCOOH}$ & 41.6 & 71.4 & 63.2 & 73.0 & 61.6 \\
\hline FAH & 16.3 & 21.7 & 23.0 & 24.4 & 21.7 \\
\hline AFAH & - & 23.8 & 32.5 & 46.9 & 37.5 \\
\hline $\mathrm{CH}_{3} \mathrm{COOH}$ & - & 13.8 & 14.0 & 27.6 & 20.8 \\
\hline $\mathrm{C}_{6} \mathrm{H}_{5} \mathrm{CHO}$ & - & 31.6 & - & - & - \\
\hline$p-\mathrm{CH}_{3} \mathrm{C}_{6} \mathrm{H}_{4} \mathrm{CHO}$ & - & - & - & - & 46.1 \\
\hline $\mathrm{C}_{2} \mathrm{H}_{2}$ & 7.3 & 4.8 & 1.4 & 2.5 & 2.2 \\
\hline $\mathrm{HCN}$ & 4.2 & 2.9 & 2.1 & 2.5 & 3.3 \\
\hline MAH & 1.7 & 1.4 & 0.7 & 1.0 & 0.6 \\
\hline GLY & 0.9 & 0.9 & 0.9 & 0.6 & 0.6 \\
\hline $\mathrm{HCHO}$ & 0.6 & 1.8 & 2.8 & 2.9 & 2.1 \\
\hline PAN & - & 2.4 & 3.9 & 3.5 & 3.8 \\
\hline $\mathrm{CH}_{4}$ & - & 2.5 & 7.6 & 3.7 & 7.6 \\
\hline MGLY & - & 0.9 & 0.7 & 1.9 & 1.8 \\
\hline
\end{tabular}

( ) : decomposition rate

from only toluene and xylene decomposition. $\mathrm{C}_{6} \mathrm{H}_{5} \mathrm{CHO}$ and $p-\mathrm{CH}_{3} \mathrm{C}_{6} \mathrm{H}_{4} \mathrm{CHO}$ are the major gaseous by-products from toluene and $p$-xylene decomposition, respectively; the other gaseous by-products are minor ones with concentrations of less than $10 \mathrm{ppm}$. The absorption corresponding to $o-\mathrm{CH}_{3} \mathrm{C}_{6} \mathrm{H}_{4} \mathrm{CHO}$ was also detected by IRAS, but its concentarion was not listed in the table, because no standard material for concetration calibration was obtained.

\section{Deposited Material}

Figure 7 shows the transmittance spectra of material deposited on a Si wafer on the planar electrode. The absorptions corresponding to substituted benzene $\left(680,750,830\right.$ and $\left.880 \mathrm{~cm}^{-1}\right)$ and polyphenyls (1000 $\left.1200 \mathrm{~cm}^{-1}\right)$ were observed in the spectra. In particular, the absorption at $750 \mathrm{~cm}^{-1}$ (di-substituted benzene) tends to increase due to $o$-xylene decomposition. Furthermore, absorptions corresponding to $\mathrm{O}=\mathrm{C}-\mathrm{O}$ $\left(1640 \mathrm{~cm}^{-1}\right), \mathrm{C}=\mathrm{O}\left(1730 \mathrm{~cm}^{-1}\right), \mathrm{C}-\mathrm{H}\left(2950 \mathrm{~cm}^{-1}\right)$ and $\mathrm{O}-\mathrm{H}\left(3400 \mathrm{~cm}^{-1}\right)$ groups were observed in all samples, while absorptions corresponding to $\mathrm{CH}_{3}$ (1374 and $2990 \mathrm{~cm}^{-1}$ ) were observed only in toluene and xylene decomposition. These functional groups are present in the molecular structures of the gaseous by-products such as $\mathrm{HCOOH}$ and FAH. However, no deposited material was observed after the decomposition of $\mathrm{HCOOH}$ by corona discharge. Therefore, intermediate by-products produced by the cleavage of aromatic rings probably contribute to the deposition of molecules containing the functional groups such as $\mathrm{C}=\mathrm{O}$ and $\mathrm{O}=\mathrm{C}-\mathrm{O}$ groups.

\section{Decomposition Processes of Benzene, Toluene and Xylene}

For the decomposition of toluene, Huang et al. (9) reported that the dissociation of a methyl group and a hydrogen atom in the methyl group from an aromatic ring initiated toluene decomposition in a dielectric barrier discharge. Namely, Huang et al. assumed that phenyl and benzyl radicals are produced at the beginning of toluene decomposition. In this work, the hypothesis by Huang et al. is adopted for the initial process of benzene, toluene and xylene decomposition. Figure 8 shows the estimated decomposition processes of (a) benzene, (b) toluene, (c) $o$ - and $m$-xylene and (d) $p$-xylene.

In benzene decomposition, phenyl radicals $\left(\mathrm{C}_{6} \mathrm{H}_{5} \cdot\right)$ are initially produced, as hypothesized by Huang et al.(9), and then the phenyl radicals are 


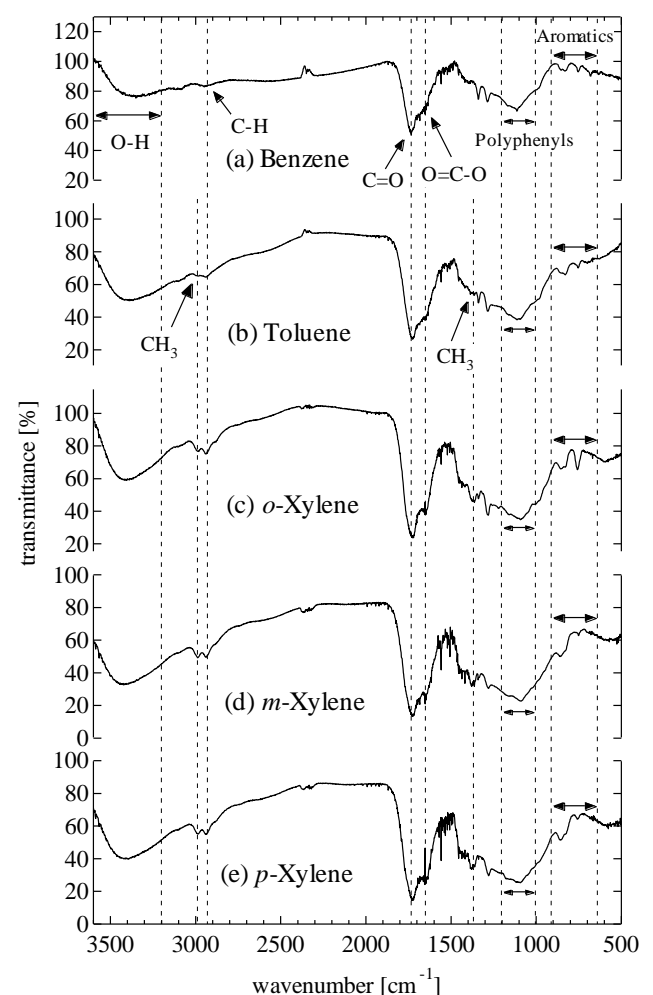

Figure 7. Transmittance spectra of deposited material.

deposited on electrodes and the walls of the discharge chamber, resulting in the polymerization of aromatic rings and the substitution of function groups. Phenyl radicals are also cleaved and converted into byproducts such as $\mathrm{CO}_{2}$ via $\mathrm{CO}, \mathrm{HCOOH}, \mathrm{FAH}$, etc, detected in Figure 3. Some intermediate by-products produced after the cleavage of the aromatic ring and containing $\mathrm{O}=\mathrm{C}-\mathrm{O}, \mathrm{C}=\mathrm{O}, \mathrm{O}-\mathrm{H}$ and $\mathrm{C}-\mathrm{H}$ groups are deposited on the electrodes.

In toluene decomposition, benzyl $\left(\mathrm{C}_{6} \mathrm{H}_{5} \mathrm{CH}_{2} \cdot\right)$ and phenyl radicals are initially produced, as shown in Figure 8 (b). These radicals are deposited and converted in the same way as described in benzene decomposition. Benzyl radicals contribute to the production of $\mathrm{AFAH}$ and $\mathrm{CH}_{3} \mathrm{COOH}$. Comparing the cases for (a) benzene and (b) toluene decomposition, benzaldehyde is produced along with benzyl radical. Thus, it was concluded that $\mathrm{C}_{6} \mathrm{H}_{5} \mathrm{CHO}$ is produced from benzyl radical, by the reaction with an $\mathrm{O}$ radical as shown in Eq.(1) (11). $\mathrm{C}_{6} \mathrm{H}_{5} \mathrm{CHO}$ is cleaved in corona discharge, and some of its fragments are deposited on the electrodes.

$$
\mathrm{C}_{6} \mathrm{H}_{5} \mathrm{CH}_{2} \cdot+\mathrm{O} \cdot \rightarrow \mathrm{C}_{6} \mathrm{H}_{5} \mathrm{CHO}+\mathrm{H} \cdot
$$

In xylene decomposition in Figures 8 (c) and (d), methyl benzyl $\left(\mathrm{CH}_{3} \mathrm{C}_{6} \mathrm{H}_{4} \mathrm{CH}_{2} \cdot\right)$ and methyl phenyl $\left(\mathrm{CH}_{3} \mathrm{C}_{6} \mathrm{H}_{4} \cdot\right)$ radicals are initially produced. Based on the manner of radical formation in toluene decomposition, shown in Figure 8 (b), methyl benzyl radicals are produced by the removal of a $\mathrm{H}$ atom from one of the methyl groups of xylene, while methyl phenyl radicals are produced by the removal of a methyl group. Those radicals are deposited on the electrodes and converted into $\mathrm{CO}_{2}$ via $\mathrm{CO}, \mathrm{HCOOH}$, $\mathrm{FAH}$, AFAH and $\mathrm{CH}_{3} \mathrm{COOH}$, in similar manner as that described in the case of toluene decomposition. Furthermore, $\mathrm{CH}_{3} \mathrm{C}_{6} \mathrm{H}_{4} \mathrm{CHO}$ is produced from methyl benzyl radicals, by the reaction with an $\mathrm{O}$ radical as shown in Eq.(2) (12), and $\mathrm{CH}_{3} \mathrm{C}_{6} \mathrm{H}_{4} \mathrm{CHO}$ is deposited and converted in a similar manner as that described for $\mathrm{C}_{6} \mathrm{H}_{5} \mathrm{CHO}$. Some intermediate by-products produced by the cleavage of the aromatic ring in benzene, toluene and xylene decomposition are also deposited on electrodes.

$$
\mathrm{CH}_{3} \mathrm{C}_{6} \mathrm{H}_{4} \mathrm{CH}_{2} \cdot+\mathrm{O} \cdot \rightarrow \mathrm{CH}_{3} \mathrm{C}_{6} \mathrm{H}_{4} \mathrm{CHO}+\mathrm{H} \cdot
$$

\section{Conclusions}

In this work, a positive DC corona discharge was generated in artificial air containing benzene, toluene or xylene. Gaseous by-products and deposited material were minutely investigated, and the decomposition processes for benzene, toluene and xylene was elucidated. Common gaseous by-products from benzene, toluene and xylene decomposition were $\mathrm{CO}_{2}, \mathrm{CO}, \mathrm{HCOOH},(\mathrm{CHO})_{2} \mathrm{O}, \mathrm{C}_{2} \mathrm{H}_{2}, \mathrm{HCN}, \mathrm{HCHO}$, $\mathrm{C}_{4} \mathrm{H}_{2} \mathrm{O}_{3}$ and $(\mathrm{CHO})_{2}$, and $\mathrm{CH}_{3} \mathrm{COOCHO}, \mathrm{CH}_{3} \mathrm{COOH}$, $\mathrm{CH}_{3} \mathrm{COOONO}_{2}, \mathrm{CH}_{4}$ and $\mathrm{CH}_{3} \mathrm{COCHO}$ were only produced in artificial air containing toluene and xylene. In addition, $\mathrm{C}_{6} \mathrm{H}_{5} \mathrm{CHO}$ and $\mathrm{CH}_{3} \mathrm{C}_{6} \mathrm{H}_{4} \mathrm{CHO}$ are produced from toluene and xylene, respectively. $\mathrm{CO}_{2}$, $\mathrm{CO}, \mathrm{HCOOH}, \quad(\mathrm{CHO})_{2} \mathrm{O}, \mathrm{CH}_{3} \mathrm{COOCHO}, \mathrm{H}$, $\mathrm{CH}_{3} \mathrm{COOH}, \mathrm{C}_{6} \mathrm{H}_{5} \mathrm{CHO}$ and $p-\mathrm{CH}_{3} \mathrm{C}_{6} \mathrm{H}_{4} \mathrm{CHO}$ were the major gaseous by-products, and the others were minor ones. In the deposited material, polyphenyls, substituted benzene, $\mathrm{C}-\mathrm{H}, \mathrm{C}=\mathrm{O}$ and $\mathrm{O}=\mathrm{C}-\mathrm{O}$ groups were found in all samples, while $\mathrm{CH}_{3}$ groups were additionally found in toluene and xylene decomposition.

It was hypothesized that the decomposition of benzene, toluene and xylene was initiated by the production of phenyl radicals, phenyl and benzyl radicals, and methyl benzyl and methyl phenyl radicals, respectively. These radicals were deposited on electrodes, walls, etc., resulting in the polymerization of aromatic rings and the substitution of function groups. Those radicals are also decomposed and converted into by-products described above. Benzyl and methyl benzyl radicals were precursors of $\mathrm{C}_{6} \mathrm{H}_{5} \mathrm{CHO}$ and $\mathrm{CH}_{3} \mathrm{C}_{6} \mathrm{H}_{4} \mathrm{CHO}$, respectively, and $\mathrm{C}_{6} \mathrm{H}_{5} \mathrm{CHO}$ and $\mathrm{CH}_{3} \mathrm{C}_{6} \mathrm{H}_{4} \mathrm{CHO}$ were probably decomposed, contributing to the production and deposition of the by-products. Furthermore, some 


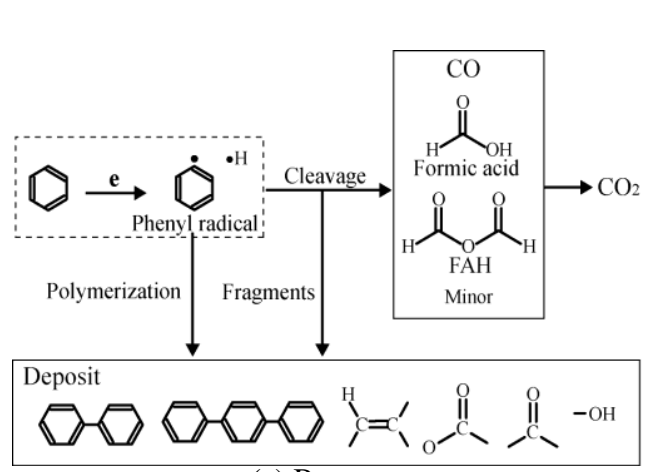

(a) Benzene.

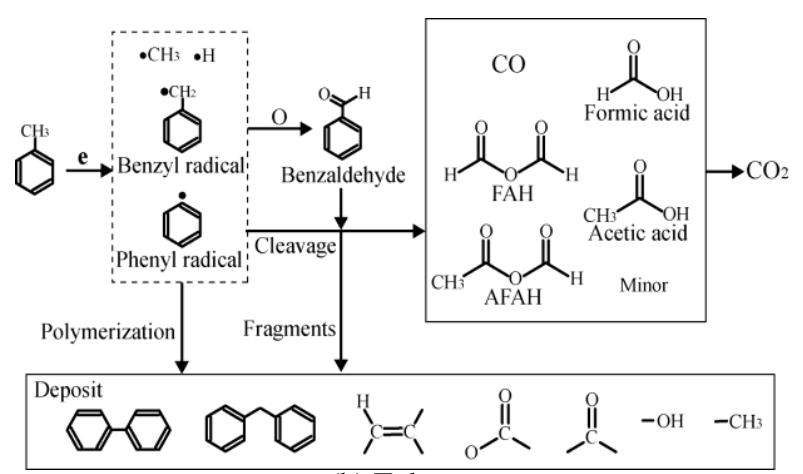

(b) Toluene.

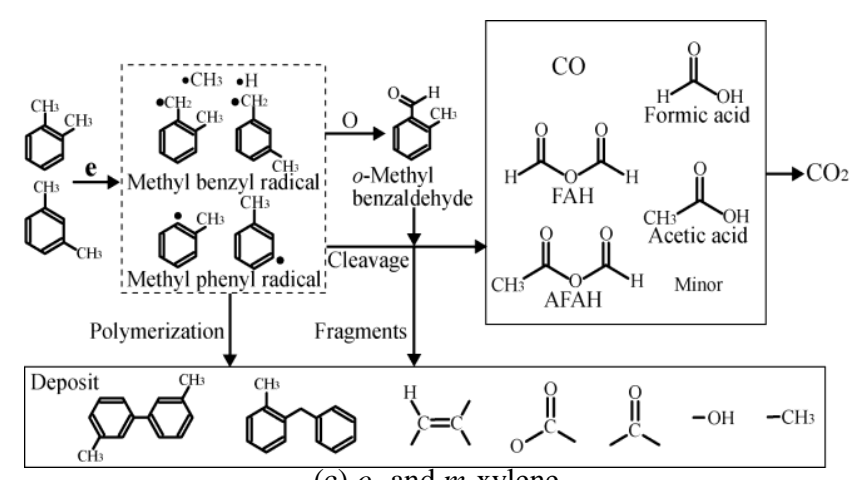

(c) $o$ - and $m$-xylene.

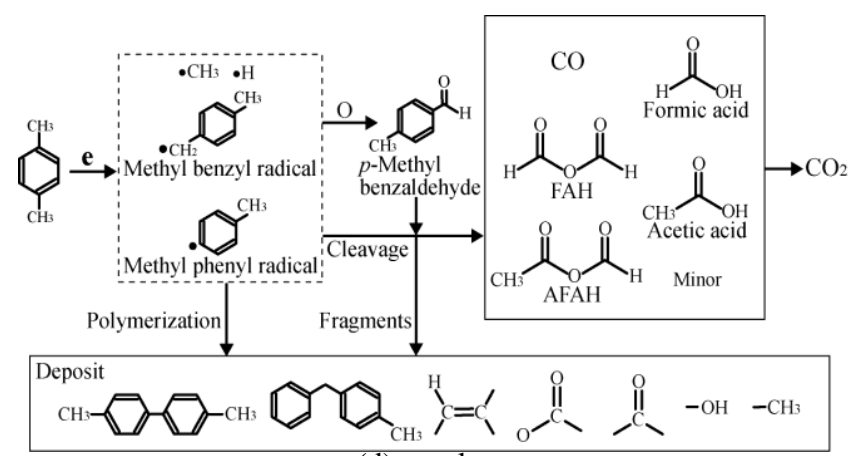

(d) $p$-xylene.

Figure 8. Estimated decomposition processes of (a)benzene, (b)toluene, (c) $o$ - and $m$-xylene and (d) $p$-xylene.

intermediate by-products produced by the cleavage of the aromatic ring during benzene, toluene, and xylene decomposition may have deposited on the electrodes.

\section{References}

(1) Urashima, K.; Chang, J.S. IEET Trans. Dielectr Electr. Insul. 2000, 7, 602-614.

(2) Sano, M.; Muneyasu, Y. Chem. Eng. Technol. 2005, $28,565-569$.

(3) Durme, J.V.; Dewulf, J.; Sysmans, W.; Leys, C.; Langenhove, H.V. Chemosphere 2007, 68, 1821-1829.

(4) Shang, K.; Wang, X.; Zhou, X.; Wang, N. J. Electrostatics 2009, 67, 746-750.

(5) Yu-Fang, G.; Dai-qi, Y.; Ke-fu, C.; Ya-feng, T. Plasma Chem Plasma Process 2006, 26, 237-249.

(6) Liang W.J.; Ma L.; Liu H.; Li J. Chemosphere 2013,
92, 1390-1395.

(7) Jiang, N.; Lu, N.; Shang, K.; Li, J.; Wu, Y. J. Hazard. Mat. 2013, 262, 387-393.

(8) Oh, S. -M.; Kim, H. -H.; Einaga, H.; Ogata, A.; Futamura, S.; Park, D. -W. Thin Solid Films 2006, 506-507, 418-422.

(9) Huang, H.; Ye, D.; Leung, D.Y.C.; Feng, F.; Guan, X. J. Mol. Catal. A : Chem 2011, 336, 87-93.

(10) Satoh, K.; Nagao, K.; Itoh, H. Trans. Mat. Res. Soc. Japan 2012, 37, 151-155.

(11) Brezinsky, K.; Litzinger, T.A.; Glassman, I. Int. J. Chem. Kinet 1984, 16, 1053-1074.

(12) Embee, J.L.; Brezinsky, K.; Glassman, I. J. Phys. Chem 1991, 95, 1626-1635.

Received for review March 10, 2015. Revised manuscript received September 22, 2015. Accepted October 9, 2015. 